\title{
Characteristics of Renal Cell Carcinoma in Dr. Hasan Sadikin General Hospital Bandung, 2010-2014
}

\author{
Dicky Suryana Putra, ${ }^{1}$ Sri Suryanti, Aaron Tigor Sihombing ${ }^{3}$ \\ ${ }^{1}$ Faculty of Medicine Universitas Padjadjaran, ${ }^{2}$ Department of Pathology Anatomy Faculty of \\ Medicine Universitas Padjadjaran/Dr. Hasan Sadikin General Hospital Bandung, ${ }^{3}$ Department \\ of Surgery Faculty of Medicine Universitas Padjadjaran/Dr. Hasan Sadikin General Hospital \\ Bandung
}

\begin{abstract}
Background: Data characteristics for renal cell carcinoma are mostly derived from developed countries. However, data from developing countries, specifically in Indonesia have not been fully described. This study aimed at describing renal cell carcinoma (RCC) characteristics based on age, gender, and histopathology type in Dr. Hasan Sadikin General Hospital Bandung.

Methods: This was a descriptive study conducted in August-October 2015. The data were collected from histopathology medical records of patients who had been diagnosed with RCC at Department of Pathology Anatomy Dr. Hasan Sadikin General Hospital Bandung, from 2010 to 2014. Total sampling was used as sampling method. Only RCC records that had complete variables; which were age, gender, and histopathological type; included in this study.

Results: There were 25 cases of renal cell carcinoma discovered in this study, 17 cases discovered in men and 8 cases discovered in women. The histopathology type found in this study was clear cell renal cell carcinoma (12 cases), papillary renal cell carcinoma (8 cases), chromophobe renal cell carcinoma (3 cases), and carcinoma of the collecting ducts of bellini ( 2 cases). There were no cases found below the age range 2-29 years old and above the age range 70-79 years old.

Conclusions: Men have higher incidence than women with the ratio of 2:1. Peak incidence is found on the age range 50-59 years old. The most common histopathology type is clear cell renal cel carcinoma. [AM].2016;3(4):644-8]
\end{abstract}

Keywords: Age, gender, histopathology type, renal cell carcinoma

\section{Introduction}

Renal cell carcinoma is the most common renal cancer (85-90\%). Its incidence and mortality rate continue to increase in many developed and developing countries. ${ }^{1-3}$ Developed countries have higher incidence and mortality rate than developing countries do. ${ }^{1,3}$ The characteristics of data for renal cell carcinoma are mostly derived from developed countries that have already had a good system for medical record registration or better health services. Therefore the characteristics of data have not yet described the situation in developing countries, specifically Indonesia., ${ }^{1,-6}$

West Java, which is the most populous province in Indonesia, from statistical data has high level of risk factors for renal cell carcinoma. Some of the risk factors are smoking, obesity, and hypertension..$^{7-10}$ West Java is the second highest province in terms of proportion of daily active smokers who are older than 10 years $(27.1 \%) .{ }^{11}$ The prevalence of hypertension and obesity in West Java are $29.4 \%$ and $15.4 \%{ }^{11}$

Dr. Hasan Sadikin General Hospital Bandung is the main referral hospital for cancer in West Java. Therefore, it is indicated that the characteristics of renal cell carcinoma based on age, gender, and histopathology type in Dr. Hasan Sadikin General Hospital Bandung are abundant. This condition meets the aim of the study, which is to describe the data characteristics.

Correspondence: Dicky Suryana Putra, Faculty of Medicine, Universitas Padjadjaran, Jalan Raya Bandung-Sumedang Km.21, Jatinangor, Sumedang, Indonesia, Phone: 085223306888 Email: trickydickky@gmail.com 


\section{Methods}

This was a descriptive study conducted in August-October 2015. The data were collected retrospectively from histopathology medical records of the patients who had been diagnosed with renal cell carcinoma at Department of Pathology Anatomy, Dr. Hasan Sadikin General Hospital Bandung in 20102014. The sampling method used was total sampling. This study had been approved by The Health Research Ethics Committee Dr. Hasan Sadikin General Hospital, Bandung.

The inclusion criteria in this study were all histopathology medical records of the patients with complete medical record (age, gender, and histopathology type), started
Table 1 Distribution of Renal Cell Carcinoma Based on Year

\begin{tabular}{lcc}
\hline & Year & Total \\
\hline 2010 & 3 \\
2011 & 1 \\
2012 & 3 \\
2013 & 8 \\
2014 & 10 \\
Total & 25 \\
\hline
\end{tabular}

from January 2010 to December 2014. There were 25 inclusion data and 0 exclusion data. However, since, some medical records were

Table 2 Distribution of Renal Cell Carcinoma Based on Age, Gender, and Type of Histopathology

\begin{tabular}{lc}
\multicolumn{1}{c}{ Variable } & Total $(\mathbf{n}=\mathbf{2 5})$ \\
\hline Age (years) & 0 \\
$0-9$ & 0 \\
$10-19$ & 2 \\
$20-29$ & 3 \\
$30-39$ & 5 \\
$40-49$ & 8 \\
$50-59$ & 6 \\
$60-69$ & 1 \\
$70-79$ & 0 \\
$>80$ & \\
Gender & 17 \\
Male & 8 \\
Female & \\
Histopathology Type & 12 \\
Clear cell renal cell carcinoma & 0 \\
Multilocular clear cell renal cell carcinoma & 8 \\
Papillary renal cell carcinoma & 3 \\
Chromophobe renal cell carcinoma & 2 \\
Carcinoma of the collecting ducts of bellini & 0 \\
Renal medullary clear cell & 0 \\
Xp11 translocation carcinoma & 0 \\
Carcinoma associated with neuroblastoma & 0 \\
Mucinous tubular and spindle cell carcinoma & 0 \\
Renal cell carcinoma, unclassified & \\
\hline & \\
\hline
\end{tabular}


lost; the data then could not be included in the study. The data that had been collected were presented in table form.

\section{Results}

There were 25 cases of renal cell carcinoma found in the Department of Pathology Anatomy Dr. Hasan Sadikin General Hospital in 5 years, from 2010 until 2014 (Table 1).

Table 2 showed that the lowest number of renal cell carcinoma cases occurred in the age range from 20 to 29 years old. Then, the number of renal cell carcinoma cases steadily increased and reached its peak in the age range from 50 to 59 years old. Renal cell carcinoma cases were discovered more frequently in men than women, with the highest type of renal cell carcinoma was clear cell renal cell carcinoma.

Table 3 showed that based on histopathology, age, and gender RCC was mostly common in male for clear cell and papillary RCC. In addition, the age range was varied among types of histopathology.

\section{Discussion}

The highest number of renal cell carcinoma cases in this study occurred in the age range of 50-59 years old, followed by the range of 60-69 years old. This result was different from the that of the WHO data stating that the age range with the highest number of renal cell carcinoma cases was at the age range of 60 to 69 years old. ${ }^{1}$ This result may be attributed by the high exposure of renal cell carcinoma's risk factors at young age. ${ }^{2,7}$

Some of the renal cell carcinoma risk factors are smoking, hypertension, and obesity. ${ }^{2,7}$ Data from Riset Kesehatan Dasar (RISKESDAS) in 2013 stated that the proportion of daily active smokers in Indonesia within the age range of 15-19 years old was $11.2 \%$, with the highest proportion of daily active smokers was in the range of 30-34 years old (33.4\%), followed by the range of 35-39 years old (32.2\%). ${ }^{11}$

In this study, there was only 1 case found in the range of 70-79 years old. This may be related to the life expectancy in Indonesia which was only 70 years. Thus the chances for renal cell carcinoma patients diagnosed at the age of 70 years were relatively smaller. ${ }^{12}$

In this study, the distribution of renal cell carcinoma was discovered more common in men than in women, with the ratio of men and women is $2: 1$. This result was similar to the data released by the WHO. ${ }^{1}$ The higher number of patients with renal cell carcinoma in men compared to those in women, may be attributed to the higher prevalence of smoking in men than in women. ${ }^{13}$ The prevalence of smokers in Indonesia in 2011 was $31.1 \%$ in men and $6.2 \%$ in women. ${ }^{11}$

The highest number of renal cell carcinoma types in Dr. Hasan Sadikin General Hospital

Table 3 Distribution of Carcinoma Based o Histopathology, Age and Gender

\begin{tabular}{lcccc}
\hline Variable & $\begin{array}{c}\text { Clear Cell Renal } \\
\text { Cell Carcinoma }\end{array}$ & $\begin{array}{c}\text { Papillary Renal } \\
\text { Cell Carcinoma }\end{array}$ & $\begin{array}{c}\text { Chromophobe } \\
\text { Renal Cell } \\
\text { Carcinoma }\end{array}$ & $\begin{array}{c}\text { Carcinoma of } \\
\text { The Collecting } \\
\text { Ducts of Bellini }\end{array}$ \\
\hline Age (years) & 0 & 0 & 0 & 0 \\
$0-9$ & 0 & 0 & 0 & 0 \\
$10-19$ & 0 & 2 & 0 & 0 \\
$20-29$ & 2 & 0 & 1 & 0 \\
$30-39$ & 4 & 0 & 1 & 0 \\
$40-49$ & 3 & 3 & 1 & 1 \\
$50-59$ & 2 & 3 & 0 & 1 \\
$60-69$ & 2 & 0 & 0 & 0 \\
$70-79$ & 0 & 0 & 0 & 0 \\
$>80$ & & & & 0 \\
Gender & & 7 & 1 & 2 \\
Male & 9 & 1 & 2 & 0 \\
Female & 3 & &
\end{tabular}


is clear cell renal cell carcinoma (12 cases), followed by papillary renal cell carcinoma $(8$ cases), chromophobe renal cell carcinoma (3 cases), and carcinoma of the collecting ducts of bellini ( 2 cases). Theorder of this highest number of renal cell carcinoma type was similar to the data from WHO. ${ }^{1}$

In this study, the highest number of clear cell renal cell carcinoma cases occurred in the 4 th decade (40-49 years old age range). These results are different from that of the WHO saying that the highest number of cases occurred in the 6th decade (60-69 years old age range). ${ }^{1}$ This may also be attributed by the high exposure of renal cell carcinoma's risk factor occurred at young age, as had been described above. ${ }^{2,7,11}$

The youngest age of the case of renal cell carcinoma in this study, occurred at 26 and 29 years old. Both cases were the cases of papillary renal cell carcinoma. This result may be caused by mutations of the Fumarate Hydrogenase gene that would increase a person's risk for developing papillary renal cell carcinoma type 2 at young age. ${ }^{14,15}$

In this study, in contrast to clear cell renal cell carcinoma and papillary renal cell carcinoma, chromophobe renal cell carcinoma and carcinoma of the collecting ducts of bellini were more common in women than men. The ratio of men to women in chromophobe renal cell carcinoma was $1: 2$.The result was different from that of the WHO saying that the comparison between men and women was relatively equal, with slightly more common cases found in men. ${ }^{1}$ However, there was other study which stated that chromophobe renal cell carcinoma occurred more frequently in women. ${ }^{16}$

This study found several obstacles in the research: there were some missing medical records so the author could not do complete data collection. Additionally, the handwriting on medical records was unclear to read, so it could cause errors in the data collection.

The conclusion of this study is that men have higher renal cell carcinoma's incidence than women with the ratio of $2: 1$. Peak incidence of this case is on the age range of 50-59 years old. The most common histopathology type is clear cell renal cell carcinoma. Further cohort study should be undertaken in order to describe the burden of the disease completely.

\section{References}

1. Kaplan W, Wirtz VJ, Manteel-Teeuwisse A, Moch H, Lash LH, Scelo G. World Cancer
Report : Kidney cancer. 2014. Lyon: International Agency for Research on Cancer, WHO; 2014. p. 631-44.

2. Chow W-H, Dong LM, Devesa SS. Epidemiology and risk factors for kidney cancer. Nat Rev Urol. 2010;7(5):245-57.

3. Znaor A, Lortet-Tieulent J, Laversanne $M$, Jemal A, Bray F. International variations and trends in renal cell carcinoma incidence and mortality. Eur Urol. 2015;67(3):51930.

4. Agnihotri S, Kumar J, Jain M, Kapoor R, Mandhani A. Renal cell carcinoma in India demonstrates early age of onset \& a late stage of presentation. Indian J Med Res. 2014;140(5):624-9.

5. Valsecchi MG, Steliarova-Foucher E. Cancer registration in developing countries: luxury or necessity? Lancet Oncol. 2008;9(2):159-67.

6. Thun MJ, DeLancey JO, Center MM, Jemal A, Ward EM. The global burden of cancer: priorities for prevention. Carcinogenesis. 2010;31(1):100-10.

7. Brennan $\mathrm{P}$, van der Hel O, Moore LE, Zaridze D, Matveev V, Holcatova I, et al. Tobacco smoking, body mass index, hypertension, and kidney cancer risk in central and eastern Europe. Br J Cancer. 2008;99(11):1912-5.

8. Lipworth L, Tarone RE, Lund L, McLaughlin JK. Epidemiologic characteristics and risk factors for renal cell cancer. Clin Epidemiol. 2009;1(1):33-43.

9. 9. Hunt JD, van der Hel OL, McMillan GP, Boffetta P, Brennan P. Renal cell carcinoma in relation to cigarette smoking: metaanalysis of 24 studies. Int J Cancer. 2005;114(1):101-8.

10. Setiawan VW, Stram DO, Nomura AM, Kolonel LN, Henderson BE. Risk factors for renal cell cancer: the multiethnic cohort. Am J Epidemiol. 2007;166(8):932-40.

11. Badan Penelitian dan Pengembangan Kesehatan. Riset Kesehatan Dasar 2013. Jakarta: Badan Penelitian dan Pengembangan Kesehatan Kementerian Kesehatan RI; 2013.

12. Badan Pusat Statistik Nasional. Indonesia Population Projection. Jakarta: Badan Pusat Statistik; 2013.

13. Jonasch E, Futreal A, Davis I, Bailey S, Kim WY, Brugarolas J, et al. State-of-thescience: An update on renal cell carcinoma. Mol Cancer Res. 2012;10(7):859-80.

14. Linehan WM, Bratslavsky G, Pinto PA, Schmidt LS, Neckers L, Bottaro D, et al. Molecular Diagnosis and Therapy of Kidney 
Cancer. Annu Rev Med. 2010;61(1):32943.

15. Kuroda N, Ohe C, Kawakami F, Mikami S, Furuya M, Matsuura K, et al. Clear cell papillary renal cell carcinoma: a review. Int J Clin Exp Pathol. 2014;7(11):7312-8.
16. Steffens S. Clinical behavior of chromophobe renal cell carcinoma is less aggressive than that of clear cell renal cell carcinoma, independent of Fuhrman grade or tumor size. Virchows Arch. 2014;465(4):439-44. 